董福祉園) は，先の研究方法を問題とし，上層と下層と に分けた場合，それらの間には，すでに知能の水準の差 が存在していると尒想されるから，社会的階層の差とい らょりる，むしろ知能の程度の差になるのではないかと いら疑啁を提起した。しかしこのことに関しては大沢 （聖母女学院短大）が補足的説明として，画階層のグル 一プは，いずれも知能において平均以上のものとい5点 で統制してある旨をのべて扣り，乙たがってこの問題は ほぼ解消されていると考えられた。

大西伎一・北尾偷裳 (735) の知能萛造と学力の研究 では, Over-Achiever と創造性との関連について恩田 から発言があった。彼は OA と創造性の間に積極的な 関連が予想されるといらのであるが，この点，大西もほ 湆同意見で，碚究の一部として創造性テストを加えたが 結果の処理の段階で充分な確信が持てず，今回はオミッ トした経過を説明した．また町田（福岡女子大）から，

OA とUA との分け方の基準について買疑があり，こ れに対し大西は，OA やUA の基礎になっている成就 值の理論から考えて，雨者を分けるはっきりした境界線 をつくることは不合理であり，乙たがって成就值そのも のの分有の中で，雨極端沈あるのの中から所望の人数 をそれぞれ抽出した旨の説明をした。 またさらに町田 は, UA が生ずる原因は, 知能構造よりも外に, もっ之 多くの大切な要因が作用しているとのべた。これに対し 大西は, この研究が進められてきた経過を概説し, 知能 構造の問題上りほか火，学力そのものの構造の分析研 究, 情意的要因として気質・性格・行動 - 態度 - 対人関 係・モチベーションなどの研究，さらにまた教師による 学習指導法の問題, 学習習慣の形成の問題などを挙げ, これらを含めた総合的なアプローチの中の一環として，

\section{8 社}

811 きようだい間の関係と性格

$$
\begin{aligned}
& \text { ○詫摩武俊（学習院大学） } \\
& \text { 寺島文子(" } " \text { ( ) }
\end{aligned}
$$

812 青年の両親に対する態度 一Q技法による一研究一

$$
\begin{gathered}
\text { ○長谷川 浩 一 ( 神葦生短期大県学 }) \\
\text { 島. 田 一 男 (聖心女子大学) }
\end{gathered}
$$

813 家族類梨尺度に関する研究り

$$
\text { 伊，藤富美(広，島大学） }
$$

ここに知能構造の問題をとりあげている旨をのべた。

宮嶋（736）の研究は，知能検査における非知的速度 因子を閆題とし，彼自身の考案による Sg テストに関す る各種の検討をしたのであるが，汇川（芝浦工大）は， この Sg テスト自身に関して若干の疑義を表明した。す なわち彼は Sg テストの index に対しては共感できる が，それぞれの作業に特有な，あるいは困難度レベルに 応じた Sg があると思われるといらのである.これに対 し宮嶋は，たしかにその通りであるが，この研究では， 知能検査の結果の全体を問題にし, それに対する Sg の 影響を検討することが主眼であるので，質問された点に 関しては，いずれは今後に研究されるべきものと思うと いう応答を与えた。

最後に宮川・佐藤 $(737,738)$ の研究は，青年期にお ける精神作業のスピード性と巧緻性に関するものであ る. 恩田は, 早く作業をするタイプのものと, 時間をか けてゆっくりやるタイプのものがあるから，このような 個人言美を考慮に入机た砳究方法が望まれる旨の発言をし た. しかしこの研究は, 結局, その問題を扱っているの であるから，したがって方法としても，ワークリミット を用いている事情が宮川より説明された。 また津留（神 戸大）は，この研究が青年期の開題として興味あるもの であることを認め，しかしながら，その目的としている スピード性と正確性との関䍹つ考察から離れて, 仙台市 と㻃村，あるいは男子と女子との比較に走りすぎている と批判した。また彼は，この研究があまりに空間知覚的 な串験にかたよりすぎているから，もっと他の精神作業

\begin{tabular}{|c|c|c|}
\hline 侤 & 田 & 明 (横浜国立大学) \\
\hline & 多 & 進 $\left(\begin{array}{l}\text { 伊 豆 長 岡 } \\
\text { 童 福 祉 園 }\end{array}\right)$ \\
\hline & 野 & 命（国際基督教大学） \\
\hline & 摩 武 & 俊（学習 \\
\hline & 村 喜 & 代 \\
\hline & 屋 有 & 牙 \\
\hline
\end{tabular}
についても垁験してみることが望ましいと述べた。

(大西佐一・宮川知彰)
814 家族関係の社会文化的背景

(1) 調査の概要 
815 家族関係の社会文化的背景

（2）家族階層・地域文化と教育環境

○土屋有子(東 京大学:

田村喜 代 (東京学芸大学)

星 野命 (国際基督教大学)

依田明(横浜国立大学:

詑摩 武俊 (学習院大学)

繁多進 (伊豆長剛 $)$

816 家族関係の社会文化的背景

（3）父母の期待を中心として

○田 村 喜 代 (東京学荟大学)

繁多進 (伊

星 野命 (国際基督教大学)

詫摩武俊 (学: 習院大学: )

土屋有子(東京大学)

依田明(横浜国立大学)

817 家族関係の社会的背景

（4）父母の達成価值志向を中心として

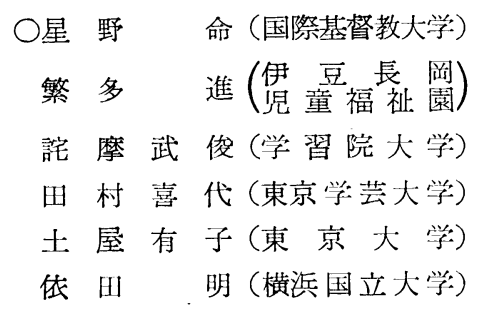

\section{I 全 体 的 特 徵}

ここでは家族関係関する7つの研究が発表された。 そのらちの 4 つは共同研究で共通の主題についての発表 であったままた，家族関係といっても，それぞれの研究 があつかったものは, きょうだい関係, 夫婦関係, 親子 関係とさまざまであった，そのために，討論は共同研究 を中心に打こなわれ，7つの発表全体にわたる共通した 主題について討議されることはなかった。一方, 星野・ 依田（814〜817）たちの共同研究者のなかには, 家政学 や教育社会学を専攻するものが含まれていたため，討論 参加者も心理専攻者にかぎられず，それぞれの学問領域 を背景とした発言が多かった，今回の討議内容が，かな らずしも次元の高いものとはいえなかったかもしれない が，隣接科学との交流が望をれる研究領域の発表の場と しては，将来の方向を志向するものとして積極的化価 すべきであると考える.な㧍，811 の発表者は，共同研 究者である詫摩武俊（学習院人学）に変更された.

\section{II 討 論の内容}

詫摩・寺島（811）の発表に対し，依田（横浜国大） は，女子ぞうしのきょうだいが仲がわるいと評価されて いるがどのような理由であると考党ているかと質問し た、詫摩は，被調查者が一般的な世間の通念に従って回 答したのであろうとのべた。また，星野（国際基督教 大）は，被調查者の自分のきょうだいに対する感情が投 射された結果ではないかとの見解はとれないかとただし た.

長谷川（812）の発表汶し, 中原（荻城大）は, 因 子の表現が適切でない，また第 I，第】因子は相補的と 発表されたが因子を相補的というのは適当でないとの 意見をのべた。長谷川は，そ机に対して，Q 分類カ一 ドを作製するさい，独立一依你という水準を考慮した が，独立のなかには拒否的な，依存のなかには愛着的な 要素がはいっていると教えた，そのために，このような 表現を用いたとの回答がなされた。

伊藤（813）の発表に対しては, 松島（共立女子大, 䣒時会員) から, 家族類型というょり, 家庭管理・経営 類型といらべきではないか，また単一次元で尺度化する より，類型化の際どの項目がより重要かを決定するべき ではないかとの質問がなされた．伊藤は，第一の点につ いては家族は夫婦中心と考鼻るから，この表現でよいと し，第二の点は将来その方向に硎究を進めたいと回答し た. 永田（名古屋大）は，妻の及が調查刘象とされい て, 夫が無視されているのは疑問だとのべた．伊藤は， 過去の経験から妻の回答のほうがより客観的であるとの べた. 長谷川は，夫と妻の回答のずれを手脚りのひとつ とする方向を指摘した．伊藤は，そのような方法を用い たい気持はあるが，回答を集める技術的な面を考虑する と夫を対象とする調査は困難であると回答した．

三つの砶究に対する討議のあと，815８17 共同研究 に対して；多くの討議がなされた，要約すると，つぎの ようであった，上屋（815）の発表に対し，長谷川（神 奈川県立衛生短大）は，4つの地域社会の階層類型を決 定する際に客観的な基準を羘いたかどらか質間した。 土 屋は, 4 つの地域社会(学校)に属する父親の学歴・職業 ・年収などを総合的に判断して類型化したと答えた。星 野は中の下，下の上などの決定は，スペシャリストとし ての土屋がいくつかの指標基づいて行なった診断であ ると補足説明をした，原岡（佐賀大）は，子どもに職業 選択させるさいに絵を使用しているが，回答者はどのよ らなレベルで（たとえば，はっきり異なった職業から一 つを選ぶとわかっていて）反応したのかと質問した，星 
野は，子どもが同じレベルで反応したことを確めること はしなかったことを認めたが，子どものばあい，職業選 択は执となとはかなり事情が異なること，またおとなの 場合でもかならずしも合理的に拉こなわ机ているとはい えない点から，子どもがどんなレベルで反応したにセ よ，絵をみて選んだことをもって，ひとつの職業選択と 考えてよいと答えた，松島は，絵を安易につかっている ように見兄る点に疑問を提出したが，星野は方法論的な 問題はないわけではないが，絵による設間は順位法のひ とつと考えて行なったので, 得られた結果は必ずしも妥 当性がないとはいえないと回答した。さらに，奥平洋子 （埼玉県中央晶童相談所）は，高林地区の父親に高校卒 の学歴をもつものが汪とんどいない理由は何かと質問し た，土屋は，高林地区は10 年抢くれた農村といわれて 抢り，この地区の往民の特殊性をしめすものであると答 えた。

田村喜代（816）に対し，原岡は職業選択の理由と基 準についての 親の回签の 相違をどう考えるかを質問し た. 田村は，選択理由の質問は選択肢の設定にも問題が あり，今回の結果は基準を中心に考えたいとのべた．原 唡は，ひとつの態度を測定するのに測定方法によって結 果に差がでるという問題点を指摘し，今後の検討の方向 を示唆した。また中原は, 職業選択の基準で, 父親と甘 親との間に差がないことから, 回答に際し両者の意見交

\section{8 社}

821 親子関係と子どものパーソナリティ形成 (1) 一CCP テストにあらわれた認知差を 中心にして一

三神 広子(一宮女子短期大学)

822 幻览期に扮ける同一視 IV

○鈴 木 淑子(東京家政大学)

八重島 建 二(神 戸大学)

823 幻児期に扮ける同一視 V

○分重島 建二(神 戸大学)

鈴 木 淑子(東京家政大学)

824 しつけの型と子供の適応性

原阔一馬（佐賀大学）

825 幼児の親子言語関係に関する研究 (3)

一家庭の社会・経济的状況との関係一

内須川洸(東京学芸大学附属 $)$
換の機会があったのではないかと蜤問した。共れに対し て，四村と星野はそのような可能性を否定できないが， 達成価值志问尺度の結果でも父母間の美はなかった。中 㬝に属する家庭では，性別による分化がなされていない ともいえると回答した。

星野命（817）に対し，伊藤富美（公島大学）は，価 值志向といら表現をつかっているが，達成動機之の関係 をどのように考えているのかと質間した，星野は，達成 動幾も 測定するためには TAT のようなものを使用し なけ机ばならない，今四の調查では挍術的に困難であっ たため，この試みは放葉した，Rosen によれば，達成 動機は非害語的なものであり，洒值志向は概念的に与之 られ形成される傾向が強い，今回の調查には，態度尺度 形式の質閵を用いたので，ことばによる質問といえる。 その意共で価值志泃と表現したと回答した。

最後に，共同研究者のひとりである詫摩は，今回の 4 つの発表は中間報告であり，結累についても完全な分析 がなされていない，また多くの指摘があったように，方 法論的にも検討が十分でなかった点も多い。けれぞも， このような専攻を異にする研究者の共同研究は，共同で おこなった地域調査や共闹討議を通じて，お互に啓発さ れることも多く，新しい視点に立つこともでき，参加者 全員にとって有意義な研究であったと総括した.

（星野 命・依田 明）

\section{会（2）}

\section{I 全 体的 特 徵}

このグループの侀究は, 親子関係と子どものパーソナ リティ形成（三神，821）および適応性（原岡，824）と の関連に関する研究それぞれ1題と，幻児期に打ける 同一視の研究 (鈴木・八重泉, $822 \cdot 3$ ), 親子言語関係 （内須川，825）に関する研究の合計 5 題である.

討論の全体的特徴：討論の大半は，親子関係と子ぞ もの適応性やパーソナリティに関する研究について展開 された.この種の研究における質問紙法上の問題点, 親 子関係硎究法上の問題点に質疑討論が集中し, 親子の関 連を問題とする研究では，父親と母親とを区分して厳密 に施行方法を規定すること，また相関関係を求める碡究 と同時に因果関係を追究する矿究の必要が論じられた。

親子言語関係の問題と同一視の問題については, 残り の短い時間，二三の質疑が交換されたにとどまった． 


\section{II 討 論の内 容}

三神（一宮女短大）の研究に対し，内須川（東学大） は，過去の経験から，児童に対する面接による值接法之 母親に対する閒接法（家庭にもち帰り記入）とでは，テ スト結果にかなりの相違がみられるのではないかと疑義 を表明した．三神は，児童と母親ともに同一の方法で契 施するプログラムを持っていることを明らかにした。 中原（茨城大）は，平均出現場面数算定法について間弓 た. 下山（東学大）は，男女児とも救助・親和・独立三 場面のうち, 救助場面の夕有意差のある点の解䣋を間う た. 三神は，母親の昼間就労が，子どもをがってやれ ぬばかりからるさがる傾向をうむ社会経済的条件を要因 にあげたが，中原からはテスト図版に問題がないか，下 山からは子どもと母親で場面設定に相違がないかなど意 見が提示され，今後の検討が約された。これに関連し CCP 梁井（福岡女学院短大）は，テストを使用した経 験から，母親と子どもの態度の相互間係は，職業婦人と 家庭婦人とでは相違し，子どもの側からの CCP では職 業婦人に受容より拒否傾向が多い事実を強調した。八重 島（神户大）からとくに職業婦人群選出に衤図があった か質閔があり，無作為抽出によることが確認された。 三 神の矿究は, 標本の問題を検討することで将来の発展が 望ま机た。

原阙（佐賀人）の研究については，先子゙原阙から次の ような耑親テストの长施上の補足説明があった，先に内 須川が指摘した方法上の䦌題を感じ，母親に封简を渡与

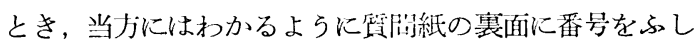
(無記名応答)，父親と母親と別々に実施したので，ある 程度は信頼でさると思う。こ机に対し内須川は，むしろ 問題となるのは母親だけに実施する場合ではないかと発 言した。また三神は，自己の研究は両親に実施したもの だが，有意差がなかったので母親の資料の久発裴したと 反証した.な括この問題に関連して八重島は，数年前の 児玉省氏の研究を紹介した，すなわち，質問紙法を両親 に実施する場合と母親単独に実施する場合とでは，そう 意味が変わらない，雨親に依頼すると，夫婦間で相談し あう場合が多いと豊富な経験から判断されるので, 親に ついては，母親から資料を収集することにしている。し かし原岡は，父親のしつけと母親のしつけとを区別して 調査する場合は，家庭のしつけを問ら場合とは違うと 反論した。これに対し森（岡山大）は，親子や両親の一 致・不一致の問題を問万場合には，やはりその方法を笽 密に規定し，その妥当性について検討する必要があるこ とを強調した。
原阔の研究結果について, 松原 (東教大) は, 子ども の適応性が消極的・積極的拒否型とは関係深いが，溺 愛・盲従烈とは関係がない具体的意味を問らた。原侕の 説明では，溺愛型の著しい母親の子どもと著しくない母 視の子どもとを比べてみると, 前者でも後者でも適応し ているものと不適心のもとあり, 子どもの適応と母親 のしつけの讶愛型との関係ははっきりしない，それに反 して, 消極的・積極的拒否型の場合は，その傾问が著し ければ著しいほど子ぞもの適応が悪くなっている。これ を受けて松原は，品川氏の親子関俰彰断テストの手引 の内容と矛盾する点（溺愛型・盲従型は不適応）を指摘 した，原岡は自己の標本に関する限り，自己の結累が事 実であると答えた，下山は，親のしつけ方に対する子ど もの認知がその不適応と関係するのか，逆に，不適応の 子ぞもなので，その認知が negative になるのか，決定 はむずかしいことを示唆した。原岡は自己の研究目的 が，現在は因果関係ではなくて相関関係を求めることに あることを明白にした後，因果関係の問題は将来の問題 として模索中であることを訴えた．この因果関係の矿究 には，適当な央験場面を設定して行なう実験的研究が重 要であることが中原から強調された。

次いで，两親間の認知のずれの問題に関して森から次 のようよな発言があった. 子ぞものしつけにとって, こ のずれの閣題だけでは一方的なことはい党ない. 子ども のことをよくいわない親とよくいら親を比べてみると， ロールシャッハによるわれわれ研究では, 前者の子ど ものハーーソナリテイの方がもしろよかった，従って「ず れ」の因果関係を分析する必要がある。八重島もまた， 罗玉氏の場合も，啟格型の視の子ぞもの方がよく適応し ていた旨紹介した．最後に松原から，一篇の愋䦗紙でも って視のしつけとみてょいかといら本質的閣題の喚起と 反省がなされ，この領野での研究扎ける因果関係の追 求の必要性が要望された。

内須川の研究に関しては，まず，方法上の問題につい て, 松原, 筒井（信大）から，職業の種類にもとずくグ ループ分けの根拠について，末た， sub-test 分類の根 拠䏓いて質問があった。これに対して内須川の返答は 次の通りである，先全く同じ資料にもとずき，地域 差・地方差・地区差がみられるか検詂したが，有意差が みられなかったので, 職業別分類による仮の分類により 今回分析したもので，特別の仮説があってのことではな い.また sub-test 分類の根拠については, 同種の研究 が海外・国内を䦥わずみられないので，止むなく，最も 関係深い之考察される親子関係の諸砳究結果従って分 
類したものである. 次に繁多 (伊豆長网览童福祉園) や 山下（能本大）は，親子言語関係㟝断テスト作成の「孙 らい」について質間した。米国の著名な言語病理学多，

Wendell Johnson は発吃理論として, Diagnosogenic theory を提唱したが，この見地から，内須川も，吃洎 診断面究の一環として，「㘥子吃音関係診断テスト」を 試作した. しかし，このテストでは対象のコントロール として正常奣を使用できないので，正常児の言語関係の 状沿を把握し, 対比しらる資料を求める必要上, 親子言 語関係を作成した。次に，内須川の竞語関係で間題とさ れている望語の内容に関する質疑が，松島（共放女大）， 筒井（信大）からなされた，前者は言語の抑揚・声量な ぞを取り扱うのか，後者は地方語などを内容として取り トゲるのかを間うものであるが，この言語関係は，広く 一般的言語を媒介とする言語関係を閌題とする旨返答が

\section{8 社}

831 交友関係に打ける親密度の測定に

関する矵究 (2)

一大学生の交友関係に打ける親密性の

強さと質についての調榃一

田中祐 次 (信州大学)

832 被説得性に関する研究 (4)

一友人関係と被説得性一

稻 越 孝 雄(東京教育大学)

833 「対話嚬度分析法」について

森 正義彥（岡山大学）

834 発表取消

835 集団準拠の構造・機能に関する発達 心理学的研究

一問題領域次元との関連による分析一

安藤 延男 (九州大学)

836 二者関係に扣ける対人感情の認知

長田雅喜 (岐 皁 大 学)

837 社会測定的地位と自己概念

○玉 瀬 耕 治 (奈良教育大学)

上由.敏 見

$838 \mathrm{PM}$ 式リーダーシップ訓練技法の研究 N

三隅 二不二（九州大学）

839 心理学実験における「計画された影響者」

としての実験者の訓練

鈴 木 康 平 (熊本大学)
あった・

最後に八重島（神戸大）・鈴木（家政大）の共同硕究 に関して，怊（京都保育尃門学院）は，役割の認知・ 対人認知といらことばで十分で，同一視といらことばを 使用しなくてもよいのではないかと間うた。 これに対し て八重島は，（時間が残されていないので）次のように 答えた. 数年前「教育心理学研究」に揭載された柏木助 教授（東女大）の「同一視の最近の砳究以関寸る文献緦 卧」を参照されればその主旨が諒解されよう．非常に大 胆に表現することが許されるならば，父一母一子関係と いら三者闺係の枠組及の中で，われれれの究極的なテ一 マである人格形成の力学を考究しつつある管徒としての フィロソフィであるとご理解頂きたい。

（分車島建二・内須川 洸）

\section{会（3）}

\section{I 全 体 的 特 徵}

本部会では “対人認知・交友関係” “意見・行動の準 拠・変容” “指導者・実験者の訓練”の分野に関する発 表が行なわれた。“対人認知・交友関係”においては, その測定のあり方，測定された地位と自己概念，感情の 認知, の諸研究が示され, “意見・行動”の面では, 被 説得性からと, 集団準拠からとの考察が行われ, “訓練” については,リーダーシップ訓練技法に関する企業組織 に打ける現場研究と, 䍒験室的研究の中に扣汁るリーダ 一としての実験者の訓練方法が論ぜられた。

討論の主眼は，社会心理学・集団力学的なアプローチ が，教育心理学的研究としてどのように位置づけられる かに関して論議がつづけられた。

\section{II 討論の内容}

一<感情の認知 $>-$

長田（836）の硼究に対して，大橋（福井大）は， $F_{1}$ （他者に対していたく感情）と $\mathrm{F}_{2}$ (他者が自己に対して いだく感情）のほかに； $\mathrm{F}_{3}$ ( $\mathrm{F}_{1}$ が他者の側にどのよう にらけとられているかの自己による推測）を導入してき たことは興味深いが， $\mathrm{F}_{3}$ の扱われ方が副次的である.

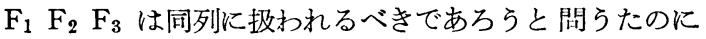
対して，長田は Tagiuri の用法に箃密に従えば, $F_{1}, F_{2}$ でもって incongruency がぞのように生じてくるかに 
ついての説明は，認知以外の 要因（たとえば自尊心な ど）でなされることが多い，これらを考えに入れる以前 に $\mathrm{F}_{1}, \mathrm{~F}_{2}$ のような第 1 段階の認知だけでなく, 第 $2 の$ 水準の認知，いわゆる $\mathrm{F}_{3}$ のようなものを今後はもっ と積極的に考察の対象としていきたいと答えた：三隅 (838) は， $\mathrm{F}_{3}$ の变化にともなって $\mathrm{F}_{2}$ の符号もかわる といら点からすれば， $F_{3}$ について適切な feedback が 行なわれた時には対人認知に変化がもたらされることが あるかと質し，原阔（佐賀大）は $F_{1}$ と $F_{2}$ の絬累とし て $\mathrm{F}_{3}$ がでてくると考えるかと質したのに対して，長田 は，“同時的に”という表現をしたいと回答した。

一<好悪感情の取り扱かいの一般論 > -

藤野（熊本大）は，一般的に対人認知の研究では，好 きは十，嫝いは一として処理しているが，十からーへ変 化するといっても，そもそも十の反対がそのまま一であ るとは限らない，あまりに単純化しすぎていないか，と 問うたのについて, 長田は, たしかに一の感情は overt に表現されにくく，その表出をちゅらちょする傾向があ るらしいことからも，十の丁度反対であるとはいえない とのべ，大橋も，三者関係における場合にも， $\mathrm{R}_{1}$ がー の時は Heider のいらーだけではないとする説むある し，一といらのは本当の意味の unit を完成しないとす る考えもあるようだが，犬゙からといって藤野のいう性質 ばかりをもつとも断言はできないと所見をのべた。

一<認知の背後にあるもの>-

森正 (838) は, 対人関係の研究に颃いては, もっと, 認知を成立させているところのメカニズムを追及する必 要がありはしないか，たとえば，なぜそれをそらみよう としているか，どらしてそうみるかという動機づけ的な ものを追及してみる必要があるとの見解をのべた，三隅 はこのことを, 対人関係の研究には, 行動観察（を通し てらる情報の貴重さ）をより主張すべきであろらかと問 題提出した. 長田は, overt behavior と sociometriclevel での対人感情とでは次元がちがっている，雨者は 対応しきれないものがあると考えると述べたのに対し て，大橋は，両者がきっぱりとちがう，あれとこれとは らがうといらのは疑問だとのべ，さらに森正は，むし ろ, overt なもの（行動）を追及しなければ，本来のも のがつかめない，両者の橋わたしの矿究が必要であると 主張した。また，田中（831）は, やはり人間は behavior の level とか perceptionの level とかいったことで 研究の主眼や，えられた資料の解秎がかわってしまらほ ぞにバラバラのものではない, overt behavior 感情と いう相互作用のうえにあるものが人間なのではないかと
述べ, 森正も, overt な level と perception (cognition）の level とを混同してものをいってはいけない が, overt と covert との関連性の追及は必要であると 強調した。

\section{- <Personality と対人認知 $>-$}

三隅は，では personality と対人認知との関係はど のようなものだらうかと質した，稻越（832）は personality が社会的な認知の中に（浮きぼりにされて）出て くるのには，かなり長期的なものを予想しておかねばな らないだろうと述心，田中も，従来の成果をみていて も，この問いに関する適確な実証資料はみあたらない， 好きを単純に十，嫝いを一とだけいっているのはどうも ピンとこない，もっと personality にかかわりのある， 質的な factor を入れたい，といら意見をのべた，森正 も，それには賛成だが，ぞこかの level で測定といら ことをしないと，いたずらに複稚になるばかりだ，十， 一だけの測定以外に，もっと現実的な strategyを（た と党ば対話頻度）とり入れた実際場面にあう力向の研究 が望まれるといい，三隅も，そのように， strategy が 入ってくると教育心理学の分野の大切な研究になってく ると所見をのべた．田中は，自分もその万向のつもりで 仲よしとひと口にいっているものを分析考慮していると いい, 原岡も，たしかに交友関係には次元が多くある， かって感情, 地位, コミュニケーション, 権力の各構造 を精査し友人関係を分析してみたことがあるが，とくに 感情面の構造は動摇著しく地位のそれは安定している結 果を見山したとのべた。

一<実験者の訓練と sensitivity >-

議論が鈴木（839）の研究にもけられた. 塩田（名古 屋大）は，鈴木は実験者の訓練を效果あらしめるものと して, 被訓練者の自己の認知, 他者の認知, それの認知 のあり方をとぎすますことにあるとの仮定をもっている ようだが，前からの議論にあったところから，認知の確 かさの向上にともなら overt behavior の变化, 対応を ぞう考えているかと質した。

これに対して鈴木は，研究の主題は実験者が実験事態 の中のひとつの要因になっていることの重要性に目をむ けたもので, 研究が要求する通りの存在の実験者を肖成 することを视らっているが，垁験者がどのような存在で あったかは，被験者の認知に依るものである. 故に実験 者としては自らが如何に見られているかと，同時に被験 者の心情も認知するように，いわば観察の基本を強く身 につけさせるということで，VTR など補助に使ってい る段階だが感受性の高まりにつれて態度の変化も認めら 
れ効果は生れつつあると推測すると答えた。

一<実践の中からさらに理論を>-

現場での PM 式リーダーシップ訓練搷法の開発に関 した三隅の研究について藤野は監督者の各層の型と生産 性の関係を問うたところ, 三隅は, 第一線監督者一従業 員の關係のみでなく Top-Middle Management一第 一線一従業員といった系列の上での, PM. P. M, pm の 組み合わせと生産性についてはすでに一部資料をとって あり，検討も加えているが，より包括的な内容の理論の
構成をめさして努力していくとのべた。

最後に牛島（青山学院大）は，全体にわたる所見と して対人認知の問題は萔児の場合には overt なもので covert な万の推察も此較的容易であろうと思われる. また感受性の 訓練や認知の feedback のさせ方の研究 が，児童の (問題) 行動の治療と結びついていくと教育 的にも更に意味のあるものがでてくると思う，その方面 への発展も期待すると結んだ.

（三隅二不二・鈴木康平）

\section{9 特 殊 教 育 (1)}

911 精神薄弱児職業教育体系化のための 基礎的研究 (5)

一問題と砳究計画一

\begin{tabular}{|c|c|c|c|c|}
\hline & 岡 & & 武 (山 & 梨 大 \\
\hline 飳 & 田 & 貞 & 雄 ( & " \\
\hline & 野 & & 武 ( & " \\
\hline , & 野 & & 環 & " \\
\hline
\end{tabular}

912 精神薄弱児職業教育体系化のための 基礎的研究 (6)

一職業的自立に必要な基本適性の

内容把握一

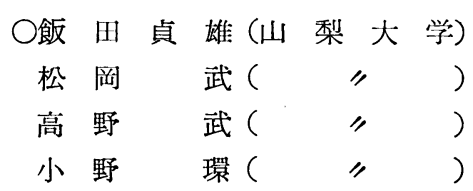

913 精神薄哥児職業教育体系化のための

基礎的研究 (7)

一職業適性の主要特質の所持実態に

関する検討一

\begin{tabular}{|c|c|c|c|c|c|}
\hline ○高 & 野 & & 武（山 & 梨 大 & 大 \\
\hline 松 & 岡 & & 武 ( & " & \\
\hline 食 & 田 & 貞 & 雄 ( & " & \\
\hline & & & 環 ( & " & \\
\hline
\end{tabular}

914 精神薄弱児の臨床教育心理学的研究

(第 5 報)一(1)

$$
\begin{aligned}
& \text { ○伊藤隆二（神 戸大学） } \\
& \text { 田川元康 (堺養護学校) } \\
& \text { 佐 藤 靖 (大阪市立大学) } \\
& \text { 寺田晃 (神戸大学) }
\end{aligned}
$$

915 精神薄弱児の臨床教育心理学的研究 (第 5 報)-(2)

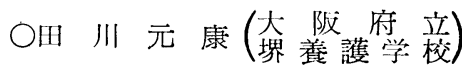

$$
\begin{aligned}
& \text { 伊藤 隆二(神戸大学) } \\
& \text { 佐 藤靖斑（大阪市立大学） } \\
& \text { 寺田晃 (神戸大学) }
\end{aligned}
$$

916 精神薄弱児の臨床教育心理学的研究 (第 5 報)一(3)

$$
\begin{aligned}
& \text { ○佐 藤 靖辰 (大阪市立大学) } \\
& \text { 伊藤 隆二(神 戸大学) }
\end{aligned}
$$

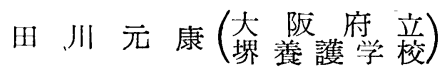

$$
\begin{aligned}
& \text { 寺田 晃 (神户大学) }
\end{aligned}
$$

917 精神薄弱児の臨床教育心理学的研究 (第 5 報)一(4)

$$
\begin{aligned}
& \text { ○寺田晃（神可大学） } \\
& \text { 伊藤隆二( ” ) } \\
& \text { 田川元康 (大险養護学校) } \\
& \text { 佐 藤 靖彥 (大阪市立大学) }
\end{aligned}
$$

\section{I 全 体 的 特 徵}

山梨大学グループの「精神薄弱児職業教育体系化のた めの基礎的研究」と, 神戸大学グループの「精神薄弱児 の臨床教育心理学的研究」の 2 つの大な共同研究の発 表に対する質疑応答が活発に拈こなわれた。

山梨大学グループの研究は特殊学級卒業生の職場での 適応要因を分析することで, 精神薄弱児の職業教育を体 系化するための基礎的資料を求めようとしたもので，主 として，テスト・調査方法によっている，すなわち，特 